\title{
Electroanalytical Methodology for the Direct Determination of 2,4-Dichlorophenoxyacetic Acid in Soil Samples Using a Graphite-Polyurethane Electrode
}

\author{
Fernanda Ramos de Andrade, Renata Alves de Toledo, and Carlos Manoel Pedro Vaz
}

Brazilian Agricultural Research Corporation, Embrapa Instrumentation, Rua XV de Novembro 1452, 13560-970, São Carlos, SP, Brazil

Correspondence should be addressed to Carlos Manoel Pedro Vaz; carlos.vaz@embrapa.br

Received 2 November 2013; Accepted 6 February 2014; Published 16 March 2014

Academic Editor: Davood Nematollahi

Copyright (C) 2014 Fernanda Ramos de Andrade et al. This is an open access article distributed under the Creative Commons Attribution License, which permits unrestricted use, distribution, and reproduction in any medium, provided the original work is properly cited.

\begin{abstract}
An electroanalytical methodology was developed for the direct determination of the herbicide 2,4-dichlorophenoxyacetic acid (2,4-D) using a graphite-polyurethane composite electrode and square wave voltammetry (SWV). 2,4-D exhibited one reduction peak with characteristics of an irreversible process at $-0.54 \mathrm{~V}$ (versus $\mathrm{Ag} / \mathrm{AgCl}$ ), which is controlled by the diffusion of the reagent on the electrode surface. After the experimental parameters optimization ( $\mathrm{pH} \mathrm{2.0,f}=50 \mathrm{~s}^{-1}, a=0.50 \mathrm{~V}$, and $\Delta E_{i}=0.03 \mathrm{~V}$ ), analytical curves were constructed in the range of $0.66 \mathrm{mg} \mathrm{L}^{-1}$ to $2.62 \mathrm{mg} \mathrm{L}^{-1}$. Detection (LD) and quantification (LQ) limits were $17.6 \mu \mathrm{g} \mathrm{L}^{-1}$ and $58.6 \mu \mathrm{g} \mathrm{L}^{-1}$, respectively. The methodology was successfully applied to measure the percolation of the herbicide 2,4-D in undisturbed soil columns of different granulometric compositions.
\end{abstract}

\section{Introduction}

2,4-D (2,4-Dichlorophenoxyacetic acid) is one of the most widely used herbicides in the world and is characterized as low-cost, quite efficient even at low concentrations, and moderately hazardous (class II) according to the World Health Organization [1]. Although this herbicide easily moves though the soil, its leaching into the groundwater can be minimized due to the degradation by microorganisms and also the absorption by plants. Its primary route of degradation in the environment is by microorganisms, which increases with temperature, humidity, $\mathrm{pH}$, and organic matter content $[2,3]$. In Brazil, the maximum acceptable concentration of 2,4-D in water is $4.0 \mu \mathrm{g} \mathrm{L} \mathrm{L}^{-1}$, according to resolution 357 of the Brazilian National Environment Council [4].

Several chromatographic [5-9] and immunoassay methods [10-13] have been used to determine 2,4-D in biological and environmental matrices. However, chromatographic methodologies are time-consuming due to the derivatization step and complex extraction procedures. Immunoassay methods use biological subtracts that may present poor stability and in some cases result in low repeatability of the analytical signals for a long analysis interval [14].

Electroanalytical procedures have been successfully applied for the determination of inorganic and organic compounds, including pesticides, in many environmental matrices, due to their good sensitivity, short time analysis, low-cost, and the possibility of sample analysis without extractions or pretreatments [15-17].

It is well known from the literature that 2,4-D exhibits poor electroactivity on most common electrode material surfaces, such as carbon, platinum, and mercury [2]. For this reason, it is crucial to develop modified electrodes for the determination and evaluation of 2,4-D. Under this circumstance, the electrochemical behavior for 2,4-D was investigated using a biosensor based on competitive immunoassay [18], an immunochemical biosensor based on a screenprinted amperometric transducer and monoclonal antibodies [19], an electrochemical sensor based on alkaline phosphatase inhibition [20], a carbon paste electrode modified with 
polyaniline [21], a glassy carbon electrode modified with cobalt chloride (III) protoporphyrin IX [22], a glassy carbon electrode modified with 2,4-D-molecular imprinted film [23], and conducting polymers (polyaniline and polypyrrole) as sensor materials [24]. However, despite the intensive use of this herbicide and its potential contamination of water resources, there is little information about the application of electroanalytical techniques for the analysis of $2,4-\mathrm{D}$ in environmental samples, which motivates additional studies in this area.

Currently, there has been an increasing interest in the use of composite electrodes for a great variety of applications [25], and the graphite-polyurethane composite electrode (GPU), developed by Mendes and coworkers [26], is an important electrode material for the determination of many compounds of environmental significance, such as organic pesticides. This electrode has been successfully used for the determination of dopamine [27], imipramine [28], hydroquinone, paracetamol and atenolol [29], rutin [30], and indole-3-acetic acid [31].

The aim of the present work is to develop, for the first time, an electroanalytical methodology to directly quantify the herbicide 2,4-D in soil samples, using the GPU electrode and the square wave voltammetry technique (SWV). The procedure was used to evaluate the behavior of 2,4-D in undisturbed soil columns under field conditions in order to determine the concentration and distribution of the applied 2,4-D along the soil profile with time and also the residual amounts of herbicide remaining in the soil after a relatively long period of time (100 days).

\section{Experimental}

2.1. Chemical and Reagents. All reagents were of analytical grade (Sigma) and were used without prior purification. All solutions were prepared with purified water from a MilliQ system (Millipore). Britton-Robinson (BR) buffer solution $\left(0.1 \mathrm{~mol} \mathrm{~L}^{-1}\right)$ was used as supporting electrolyte. The $\mathrm{pH}$ of the solutions was adjusted with $1.0 \mathrm{~mol} \mathrm{~L}^{-1} \mathrm{NaOH}$. Stock standard solution of $2,4-\mathrm{D}$ herbicide $\left(221 \mathrm{mg} \mathrm{L}^{-1}\right)$ was prepared in methanol, kept under refrigeration, and protected from light.

2,4-D commercial formulation (DMA 806 BR-Dow AgroSciences Industrial LTDA) was obtained in the local market with a declared amount of $670 \mathrm{~g} \mathrm{~L}^{-1}$. A stock solution of the commercial formulation $\left(403 \mathrm{mg} \mathrm{L}^{-1}\right)$ was prepared in aqueous media, kept under refrigeration, and protected from light as well. The 2,4-D commercial formulation was applied to the soil surface using a watering container at the maximum amount specified by the manufacturer $\left(50.3 \mathrm{mg} \mathrm{L}^{-1}\right)$. For a uniform distribution of the herbicide, both soils were carefully irrigated with 6 liters of water, just after the herbicide application.

2.2. Instrumentation. Voltammetric measurements were performed using a potentiostat/galvanostat AUTOLAB PGSTAT 30 in an electrochemical cell made from borosilicate glass with a Teflon cover, which contains orifices to insert the working (GPU), reference $\left(\mathrm{Ag} / \mathrm{AgCl}-\mathrm{KCl} 3.0 \mathrm{~mol} \mathrm{~L}^{-1}\right)$, and auxiliary (platinum wire) electrodes and for nitrogen purging.

The GPU electrode was constructed by mixing graphite and polyurethane resin at the ratio 60:40 (w/w) [26]. There is no special condition for electrode storage. The easy and fast regeneration of the GPU electrode surface was achieved by polishing the electrode disk surface with a 2,000 grit sand paper before each measurement to get a clean and reproducible electrode surface.

2.3. Electroanalytical Methodology. Analytical curves were obtained through the external standard calibration procedure. The sensitivity was checked by the limit of detection $(\mathrm{DL}=3 \sigma / \theta)$ and quantification $(\mathrm{QL}=10 \sigma / \theta)$, where $\sigma$ is the standard deviation of ten voltammograms registered for the blank and $\theta$ is the slope of the analytical curve [32] for an average of six curves.

The precision was calculated by the relative standard deviation (RSD) and checked by an experiment performed in one day ( $n=10$, intra-assay precision/repeatability) as well as by experiments in different days $(d=6$, interassay precision/intermediate precision), with a $0.33 \mathrm{mg} \mathrm{L}^{-1} 2,4-\mathrm{D}$ solution.

The accuracy was evaluated in terms of relative error (bias \%) obtained from 2,4-D recovering experiments for two soils (sandy and clayey). The experiments were performed ( $n=3$ ) by adding $100 \mathrm{~mL}$ of water to $5.0 \mathrm{~g}$ of dried soil. The mixture was fortified with a $0.33 \mathrm{mg} \mathrm{L}^{-1} 2,4-\mathrm{D}$ solution (i.e., spiked with $150 \mu \mathrm{L}$ from a $221 \mathrm{mg} \mathrm{L}^{-1} 2,4-\mathrm{D}$ stock solution), agitated for $24 \mathrm{~h}$ in a horizontal shaker, and centrifuged for $20 \mathrm{~min}$ at $13,500 \mathrm{rpm}$ (Sorvall SL-50T Rotor, diameter $=22.2 \mathrm{~cm}$ ). The $\mathrm{pH}$ of the supernatant was adjusted to 2.0 with concentrated phosphoric acid and the concentration of 2,4-D was determined with the previously developed electroanalytical method by means of a standard addition procedure, where $50 \mu \mathrm{L}$ of a $221 \mathrm{mg} \mathrm{L}^{-1} 2,4$-D stock solution was used to obtain concentrations of $0.88,1.43$, and $1.97 \mathrm{mg}$ $\mathrm{L}^{-1}$ of 2,4-D. The 2,4-D estimated concentration was directly obtained through extrapolation, in the $x$-axis, from the linear regression of the $I_{p}$ versus $C_{2,4-\mathrm{D}}$ curves.

The robustness of the methodology was checked during the optimization of the electrolyte $\mathrm{pH}$. After selecting the best $\mathrm{pH}$ value, a small $\mathrm{pH}$ variation study was done near this region in order to measure the methodology capacity to remain unaffected by short-term $\mathrm{pH}$ fluctuations. A statistical analysis was performed ( $t$-test with a $95 \%$ confidence interval) to estimate the effect of small $\mathrm{pH}$ variation on the methodology performance.

2.4. Soil Columns Experiments. The commercial herbicide formulation was applied to the surface of two types of soil, a sandy textured (AM1) and a medium clayey textured soil (AM2).

Soil samples were chemically $\left(\mathrm{pH}\right.$ in $\mathrm{CaCl}_{2}$, organic matter-OM and cation exchange capacity-CEC) and physically (clay, silt, and sand percentages) characterized in the soil laboratory PIRASOLO, Piracicaba, São Paulo, Brazil. 


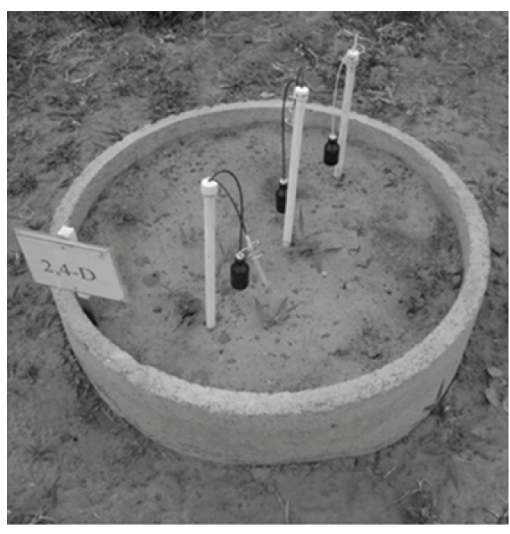

(a)

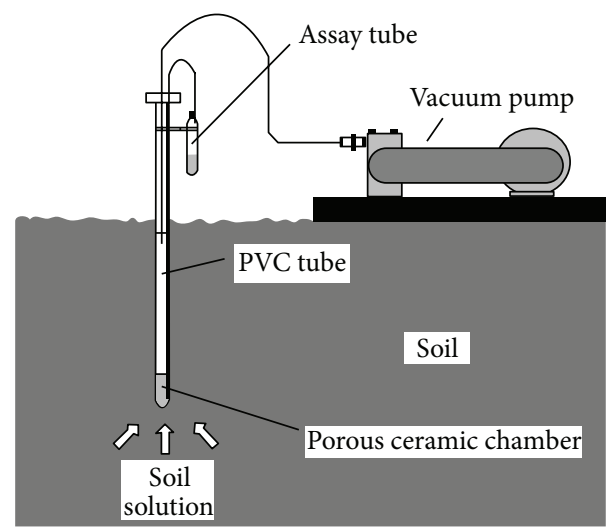

(b)

FIGURE 1: (a) Undisturbed soil in cement cylindrical containers. (b) Soil solution extraction system.

Undisturbed soil cores were packed in cement cylindrical containers with a total volume of $1.0 \mathrm{~m}^{3}$ capacity (Figure 1). After the herbicide application, the soil containers were kept uncovered to sunlight and rainfall to provide the herbicide natural transport and degradation along the soil profile. Water percolation was monitored at depths of 25, 50, and $75 \mathrm{~cm}$ for three months. Soil solutions were obtained using porous cup extractors made of silicon carbide $(\mathrm{SiC})$, which were installed in each cement container, at the same aforementioned depths. After 100 days from the beginning of the experiment, soil samples were collected with a Dutch-type auger at the same sampling depths and in all the cement containers. These soil samples were used to determine the residual amounts of the herbicide remaining in both soils. Soil solutions were also collected from the three depths before application of the herbicide. Soil containers with no herbicide addition (blank) were also prepared, sampled, and analyzed for comparison. Figure 1 presents the field experimental setup with three soil solution extractors and the vacuum pump used to collect the soil solutions in three depths.

The collected soil solutions were buffered and directly analyzed using the developed electroanalytical procedure. All the disturbed soil samples extracted $(5 \mathrm{~g})$ at the end of the experiment were treated with $1.0 \mathrm{~mL}$ of acidified water pH $1.0\left(\mathrm{H}_{2} \mathrm{SO}_{4} 9.0 \mathrm{~mol} \mathrm{~L}^{-1}\right)$ and $15 \mathrm{~mL}$ of dichloromethane. The herbicide was extracted by an ultrasound system for $1 \mathrm{~h}$. The extracts were combined and filtered through quantitative paper. The final extract was reduced in a rotary evaporator up to $1.0 \mathrm{~mL}$. To certify that all the dichloromethane was evaporated, a flux of $\mathrm{N}_{2}$ was applied over the extract for $2 \mathrm{~min}$. The final extract was then diluted in $20 \mathrm{~mL}$ of BR buffer solution and analyzed with the developed electroanalytical procedure.

\section{Results and Discussion}

The voltammetric response of 2,4-D $\left(10.5 \mathrm{mg} \mathrm{L}^{-1}\right)$ was initially evaluated and compared using different carbon working electrodes, such as glassy carbon (GC), carbon paste (CP) electrode, and GPU. Figure 2 illustrates the square wave

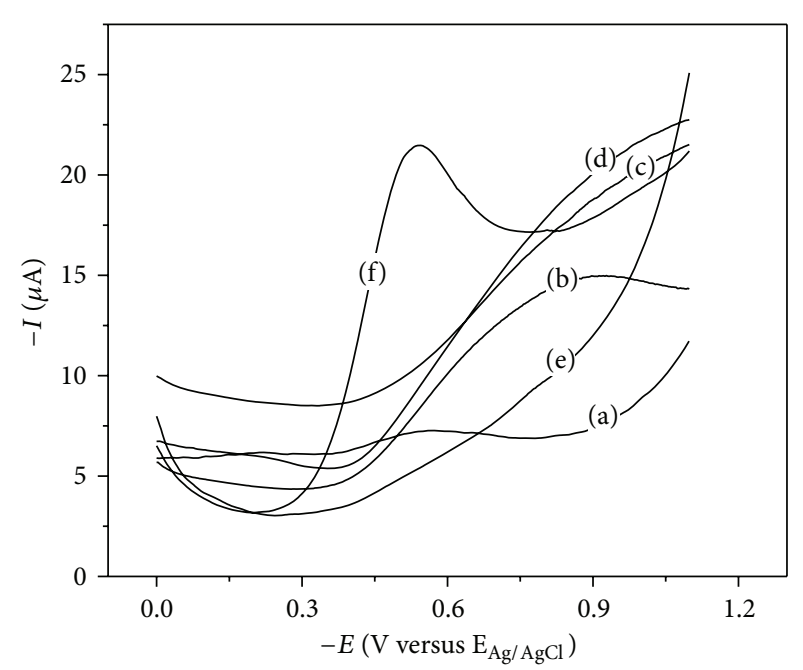

FIgURE 2: SWV curves for 2,4-D $\left(10.5 \mathrm{mg} \mathrm{L}^{-1}\right)$ in $0.1 \mathrm{~mol} \mathrm{~L}^{-1} \mathrm{BR}$ buffer solution ( $\mathrm{pH}$ 2.0) obtained using different working electrodes: (a) blank in glassy carbon, (b) 2,4-D in glassy carbon, (c) blank in carbon paste, (d) 2,4-D in carbon paste, (e) blank in GPU, and (f) 2,4-D in GPU. Parameters: $f=50 \mathrm{~s}^{-1}, a=0.50 \mathrm{~V}, \Delta E_{i}=0.03 \mathrm{~V}, t_{\mathrm{acc}}$ $=10 \mathrm{~s}$, and $E_{\mathrm{acc}}=0.0 \mathrm{~V}$.

voltammograms of each working electrode in $0.1 \mathrm{~mol} \mathrm{~L}^{-1} \mathrm{BR}$ buffer solution ( $\mathrm{pH} 2.0)$.

2,4-D presents a very well-defined reduction peak on the GPU electrode at $-0.54 \mathrm{~V}$ (versus $\mathrm{Ag} / \mathrm{AgCl}$ ), whereas on the $\mathrm{GC}$ and on the $\mathrm{CP}$ electrodes the reduction process exhibits broadened and poor voltammetric profiles. The best response of the GPU electrode suggests a favorable interaction between the polyurethane and the herbicide that results in a more effective electron transfer process.

3.1. Cyclic Voltammetric Studies. 2,4-D voltammetric curves were registered in the range of $10-500 \mathrm{mV} \mathrm{s}^{-1}$ (Figure 3) to investigate the degree of reversibility of the electrode process and also to determine the predominate type of mass transport. The irreversibility nature of the reaction is suggested by 


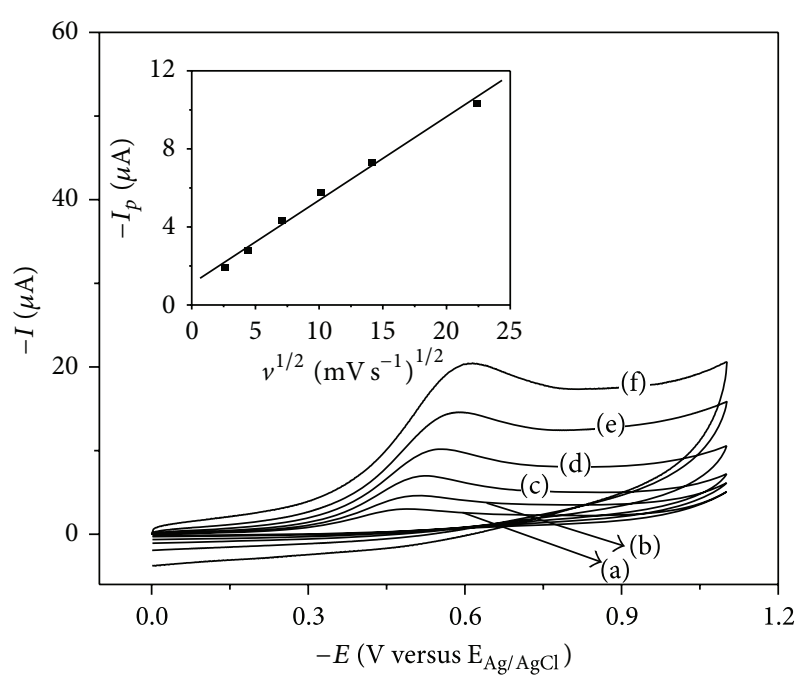

FIgURe 3: CV curves for 2,4-D (10.5 $\left.\mathrm{mg} \mathrm{L}^{-1}\right)$ in $0.1 \mathrm{~mol} \mathrm{~L}^{-1} \mathrm{BR}$ buffer solution (pH 2.0). Scan rate: (a) 10, (b) 20, (c) 50, (d) 100, (e) 200, and (f) $500 \mathrm{mV} \mathrm{s}^{-1}$. Inset: $I_{p}$ versus $v^{1 / 2}$ graph $\left(r^{2}=0.995\right)$.

the absence of anodic peak in the reverse scan and confirmed by the linear displacement of the peak potential $\left(E_{p}\right)$ with the increase of the scan rate [33]. From the linearity of $I_{p}$ versus $v^{1 / 2}$ graph (inset of Figure 3, $I_{p}(\mu \mathrm{A})=0.99+0.44 v^{1 / 2}(\mathrm{mV}$ $\left.\left.\mathrm{s}^{-1}\right)^{1 / 2}, r^{2}=0.995\right)$, it is possible to conclude that the ratelimiting step of the 2,4-D electrochemical reaction at GPU electrode is diffusion-controlled [34]. A plot of $\log I_{p}$ versus $\log v$ gave a straight line $\left(\log I_{p}(\mu \mathrm{A})=-0.11+0.42 \log v\right.$ $\left.\left(\mathrm{mV} \mathrm{s}^{-1}\right), r^{2}=0.995\right)$ with a slope of 0.42 , very close to the theoretical value of 0.50 , which is expected for a diffusioncontrolled process [34].

3.2. Electroanalytical Determination of 2,4-D. SWV was chosen from other electroanalytical techniques due to its high sensitivity and fast voltammograms acquisition. In order to obtain the best analytical signal for 2,4-D, some experiments were performed to optimize the electrolyte $\mathrm{pH}$ and the acquisition parameters of the SWV technique, namely, frequency $(f)$, pulse amplitude $(a)$, scan increment $\left(\Delta E_{i}\right)$, accumulation time $\left(t_{\text {acc }}\right)$, and accumulation potential $\left(E_{\text {acc }}\right)$.

The effect of the $\mathrm{pH}$ was studied in the range of 2.0 to 8.0. The cathodic peak potential shifted linearly $(\mathrm{dE} / \mathrm{dpH}=$ $-0.064 \mathrm{~V} / \mathrm{pH}$ ) to more negative potentials for $\mathrm{pH}$ ranging from 2.0 to 3.5, indicating that $\mathrm{H}^{+}$is involved in the electrode reaction. The best analytical signal was obtained in $\mathrm{pH} 2.0$, which was then selected for the analytical applications.

The slope of $-0.064 \mathrm{mV} / \mathrm{pH}$ is close to the Nerstian $-0.059 \mathrm{mV} / \mathrm{pH}$ and consequently indicates that equal numbers of electrons and protons were involved in the electrochemical reduction of 2,4-D. From the literature, it is suggested that 4 electrons and 4 protons participated in the reduction of the acid carboxylic group to the correspondent alcohol [35].
The frequency was optimized in the range of $10 \mathrm{~s}^{-1}$ to $100 \mathrm{~s}^{-1}$ and for analytical purposes, a frequency value of $50 \mathrm{~s}^{-1}$ was selected. The pulse amplitude $(0.10$ to $0.50 \mathrm{~V})$ and the scan increment $(0.01$ to $0.05 \mathrm{~V})$ were also varied and the best values for these parameters were $0.50 \mathrm{~V}$ and $0.03 \mathrm{~V}$, respectively.

Although the reaction is controlled by diffusion, adsorption plays an important role in the electroanalytical signal of 2,4-D on the GPU electrode. For this reason, the accumulation potential and time were also studied. It was observed that accumulation times higher than $10 \mathrm{~s}$ did not significantly increase the analytical signal, due to the saturation of the GPU electrode surface. The accumulation potential $\left(E_{\text {acc }}\right)$ also affects the analytical signal with the highest peak current obtained for $E_{\text {acc }}=-0.40 \mathrm{~V}$. This behavior suggests that only the reagent adsorbs on the electrode surface, since the electrode reaction occurs at $-0.54 \mathrm{~V}$. Therefore, the accumulation potential and time were selected as $-0.40 \mathrm{~V}$ and $10 \mathrm{sec}$ for the subsequent analytical studies.

After optimizing the voltammetric acquisition parameters, analytical curves were obtained in the range of 0.66 to $2.62 \mathrm{mg} \mathrm{L}^{-1}$ in BR buffer solution ( $\mathrm{pH} 2.0$ ). The linear regression equation for the analytical curves was $I_{P}(\mu \mathrm{A})$ $=(0.86 \pm 0.09)+(4.47 \pm 0.05) C_{2,4-\mathrm{D}}\left(\mathrm{mg} \mathrm{L}^{-1}\right)$, with a determination coefficient $r^{2}=0.999$. A detection limit (DL) of $17.6 \mu \mathrm{g} \mathrm{L}^{-1}$ and a quantification limit (QL) of $58.6 \mu \mathrm{g} \mathrm{L}^{-1}$ were obtained according to the procedure described in Section 2.3. The precision was checked in terms of intra-assay precision (repeatability) and interassay precision (intermediate precision). The RSD values for these statistical parameters were $2.5 \%$ and $3.9 \%$, respectively.

Average recovered values of 2,4-D (concentration level: $0.33 \mathrm{mg} \mathrm{L}^{-1}$ ) in both soils were $93.6 \% \pm 1.2 \%$ for the sandy soil (AM1) and $94.6 \% \pm 4.2 \%$ for the clayey soil (AM2). The accuracy was evaluated in terms of the relative errors (bias $\%)$, which describes the deviation from the expected values in fortified samples. The obtained bias values were $6.8 \%$ for soil AM1 and 5.8\% for soil AM2, which are within acceptable limits. The robustness, checked by small variations on the electrolyte $\mathrm{pH}$ (i.e., from 1.8 to 2.2 ) was satisfactory, since there is a $95 \%$ probability that the true population parameter (peak current) is between $5.09 \mu \mathrm{A}$ and $6.98 \mu \mathrm{A}$.

In order to check the applicability of the developed electroanalytical procedure for soil solutions without previous treatment, analytical curves for 2,4-D were also obtained in the same concentration range as previously discussed for the supporting electrolyte in clayey and sandy soil solutions. Figure 4 shows square wave voltammograms for varying concentrations of 2,4-D in the clayey soil solution. The insert shows the analytical curves for both soils and for $\mathrm{BR}$ buffer solution. The obtained linear regression equations were $I_{P}(\mu \mathrm{A})=(0.85 \pm 0.12)+(4.57 \pm 0.07) \times C_{2,4-\mathrm{D}}(\mathrm{mg}$ $\left.\mathrm{L}^{-1}\right), r^{2}=0.999$ for the sandy soil and $I_{P}(\mu \mathrm{A})=(1.01 \pm 0.10)$ $+(3.99 \pm 0.05) \times C_{2,4-\mathrm{D}}\left(\mathrm{mg} \mathrm{L}^{-1}\right), r^{2}=0.999$ for the clayey soil. Results show no significant differences in the analytical sensitivity of the method when comparing electrolyte $\left(4.85 \pm 0.13 \mu \mathrm{A} \mathrm{mg} \mathrm{L}^{-1}\right)$ with sandy $\left(4.57 \pm 0.07 \mu \mathrm{A} \mathrm{mg} \mathrm{L}^{-1}\right)$ and clayey soil solutions $\left(3.99 \pm 0.05 \mu \mathrm{A} \mathrm{mg} \mathrm{L^{-1 }}\right)$. 
TABLE 1: Comparison between the proposed electroanalytical methodology and other ones already published in the literature for the detection of 2,4-D.

\begin{tabular}{|c|c|c|c|c|c|c|c|}
\hline Electrode & Technique & $\mathrm{pH}$ & $\begin{array}{l}\text { Linear range } \\
\left(\mathrm{mg} \mathrm{L}^{-1}\right)\end{array}$ & $\begin{array}{c}\mathrm{LD} \\
\left(\mu \mathrm{g} \mathrm{L}^{-1}\right)\end{array}$ & Sample & Recovery & References \\
\hline $\begin{array}{l}\text { Graphite-polyurethane } \\
\text { composite electrode }\end{array}$ & SWV & 2 & $0.66-2.62$ & 17.6 & Soil & $\begin{array}{c}93.6 \% \pm 1.2 \% \text { (sandy soil) } \\
94.6 \% \pm 4.2 \% \text { (clayey soil) }\end{array}$ & This work \\
\hline Static mercury drop electrode & $\mathrm{DPV}$ & 2.3 & $0.075-1.75$ & 50 & Water and soil & $\begin{array}{c}70-85 \% \pm 7 \% \text { (soil) } \\
90-95 \% \pm 2 \% \text { (tap water) } \\
80-90 \% \pm 5 \% \text { (well water) } \\
90 \% \pm 6 \% \text { (river water) }\end{array}$ & {$[2]$} \\
\hline $\begin{array}{l}\text { Silica-gel modified carbon } \\
\text { paste electrode }\end{array}$ & Amperometry & 5 & $0-2.21$ & 99.5 & Water & - & {$[35]$} \\
\hline $\begin{array}{l}\text { Molecularly imprinted } \\
\text { polypyrrole membrane }\end{array}$ & $\mathrm{CV}$ & 6.86 & $0.22-22.1$ & 183.5 & Water & $92-108 \%$ & {$[36]$} \\
\hline
\end{tabular}

TABLE 2: Some physicochemical parameters of the soil studied.

\begin{tabular}{lccccc}
\hline Sample & $\mathrm{pH} \mathrm{CaCl}_{2}$ & $\begin{array}{c}\text { Organic matter } \\
\left(\mathrm{g} \mathrm{dm}^{-3}\right)\end{array}$ & $\begin{array}{c}\text { Cation exchangeable capacity } \\
\left(\mathrm{mmol}_{\mathrm{c}} \mathrm{dm}^{-3}\right)\end{array}$ & Clay \% & Silt \% \\
\hline AM1 0-25 cm & 5.1 & 12 & 44 & 6.2 & 0.8 \\
AM1 25-50 cm & 5.3 & 3 & 29 & 7.1 & 0.9 \\
AM1 50-75 cm & 5.2 & 6 & 37 & 6.1 & 1.9 \\
AM2 0-25 cm & 5.1 & 21 & 74 & 36.9 & 10.1 \\
AM2 25-50 cm & 5.2 & 15 & 67 & 42.8 & 12.2 \\
AM2 50-75 cm & 5.4 & 8 & 58 & 39.9 & 45 \\
\hline
\end{tabular}

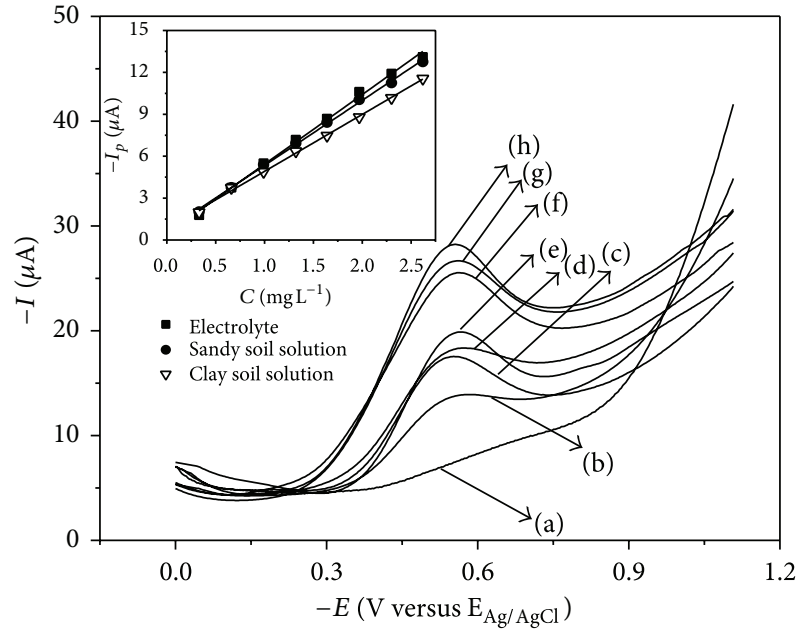

FIGURE 4: SWV curves for different 2,4-D concentrations in clayey soil solution. Concentration: (a) blank, (b) 0.66, (c) 0.99, (d) 1.32, (e) 1.64, (f) 1.97, (g) 2.30, and (h) $2.62 \mathrm{mg} \mathrm{L}^{-1}$ Parameters: $\mathrm{pH} 2.0, f=$ $50 \mathrm{~s}^{-1}, a=0.50 \mathrm{~V}, \Delta E_{i}=0.03 \mathrm{~V}, E_{\mathrm{acc}}=-0.40 \mathrm{~V}$, and $t_{\mathrm{acc}}=10 \mathrm{~s}$. Inset: analytical curves in electrolyte $(\boldsymbol{\square})$, sandy $(\bullet)$, and clayey $(\nabla)$ soil solutions.

Thus, the direct analysis of 2,4-D in soil solutions can be performed without significant interferences of dissolved solutes and colloids present in the soil solution.

Table 1 shows the comparison between the proposed electroanalytical methodology (GPU/SWV) and other ones already published in the literature for the determination of
2,4-D. The detection limit of the GPU/SWV methodology is lower than the others previously reported $[2,35,36]$. Moreover, high degrees of recovery were obtained in soil samples with standard deviations lower than 5\%, suggesting the feasibility of the proposed methodology. In general, GPU electrode is an environmental friendly option comparing to the use of mercury electrodes and it is simple, fast regeneration and good stability open the possibility of its use for the analysis of other environmental contaminants.

3.3. Percolation of 2,4-D in Soil Columns. After evaluation of the applicability of the GPU electrode for determining 2,4-D in soil solutions without previous treatment, the electroanalytical procedure was also applied to study transport and percolation of 2,4-D in two soils (sandy and a clayey textured), which were previously submitted to commercial herbicide solution treatment, according to the experimental procedure described in Section 2.4.

Table 2 presents some physicochemical properties of the soils evaluated. Soil AM1 is a sandy soil and AM2 is a medium texture soil with $40 \%$ clay (designated here as clayey soil). The $\mathrm{pH}$ values of the two soils are similar ( $\mathrm{pH}$ around 5) and did not change significantly along the soil profiles. The amount of organic matter (OM) and cation exchange capacity (CEC) contents are higher for the clayey soil and decreased with depths as expected (higher concentration of roots and more decomposed materials close to the soil surface).

Table 3 shows the measured concentrations of 2,4-D in the extracted soil solutions, using the developed electroanalytical methodology, at different depths for soils AM1 


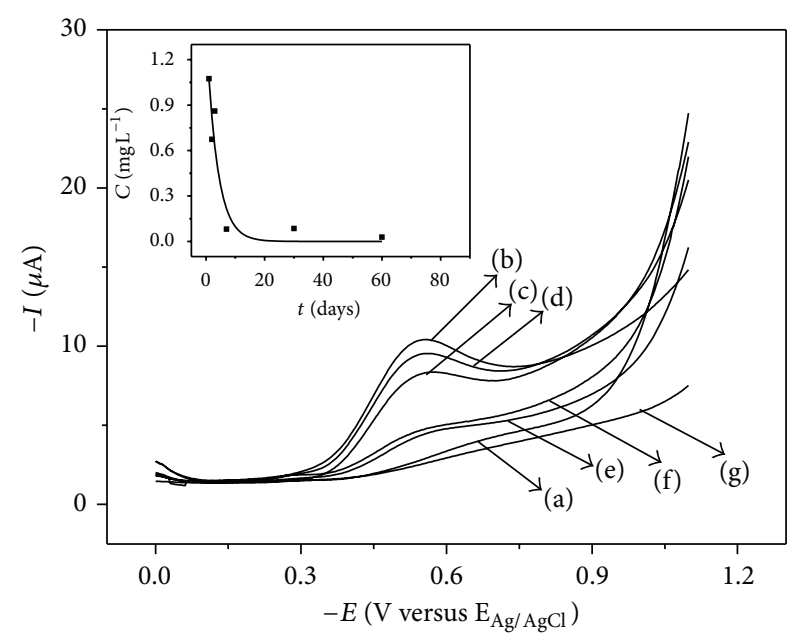

(a)

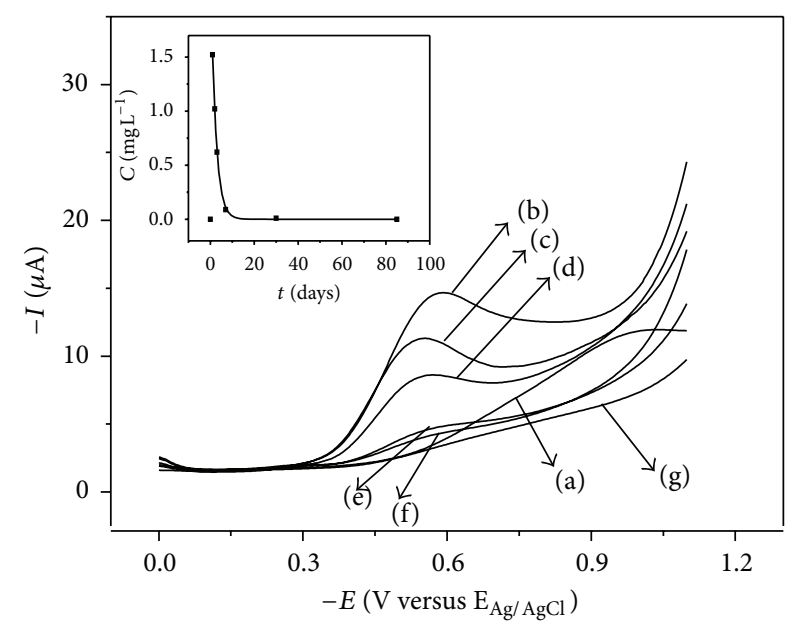

(b)

FIGURE 5: SWV curves for the 2,4-D herbicide in the two soil solution samples extracted at a $25 \mathrm{~cm}$ depth. (a) AM1 and (b) AM2. Parameters: $f=50 \mathrm{~s}^{-1}, a=0.50 \mathrm{~V}, \Delta E_{i}=0.03 \mathrm{~V}, t_{\mathrm{acc}}=10 \mathrm{~s}$, and $E_{\text {acc }}=-0.40 \mathrm{~V}$. Inset: decay of concentration with time. Samples: (a) sample without herbicide, (b) 24 hours, (c) 48 hours, (d) 72 hours, (e) 7 days, (f) 30 days, and (g) 60 days for AM1 and (a) sample without herbicide, (b) 24 hours, (c) 48 hours, (d) 72 hours, (e) 7 days, (f) 30 days, and (g) 85 days for AM2.

TABLE 3: Concentration of 2,4-D in the soil solutions extracted with the porous cup extractor system in three depths for soils AM1 and AM2.

\begin{tabular}{|c|c|c|c|c|c|c|}
\hline \multirow{3}{*}{ Sample } & \multicolumn{6}{|c|}{ Concentration of 2,4-D $\left(\mathrm{mg} \mathrm{L}^{-1}\right)$} \\
\hline & \multicolumn{3}{|c|}{ AM1 } & \multicolumn{3}{|c|}{ AM2 } \\
\hline & $25 \mathrm{~cm}$ & $50 \mathrm{~cm}$ & $75 \mathrm{~cm}$ & $25 \mathrm{~cm}$ & $50 \mathrm{~cm}$ & $75 \mathrm{~cm}$ \\
\hline $\mathrm{SH}^{\mathrm{a}}$ & $\mathrm{ND}^{\mathrm{c}}$ & ND & ND & ND & ND & ND \\
\hline $\mathrm{BR}^{\mathrm{b}}$ & ND & $\mathrm{SA}^{\mathrm{d}}$ & ND & SA & SA & SA \\
\hline $24 \mathrm{~h}$ & $1.07 \pm 0.01$ & SA & ND & $1.52 \pm 0.03$ & ND & $0.73 \pm 0.02$ \\
\hline $48 \mathrm{~h}$ & $0.67 \pm 0.07$ & SA & SA & $1.02 \pm 0.07$ & $1.19 \pm 0.03$ & $0.85 \pm 0.06$ \\
\hline $72 \mathrm{~h}$ & $0.86 \pm 0.08$ & SA & $0.62 \pm 0.03$ & $0.62 \pm 0.02$ & SA & $0.55 \pm 0.07$ \\
\hline 7 days & ND & SA & SA & ND & $0.17 \pm 0.01$ & $0.17 \pm 0.03$ \\
\hline 14 days & ND & $0.19 \pm 0.02$ & ND & ND & ND & ND \\
\hline 30 days & ND & $0.17 \pm 0.05$ & ND & ND & ND & ND \\
\hline 52 days & ND & ND & ND & SA & ND & ND \\
\hline 60 days & ND & ND & ND & ND & ND & ND \\
\hline 71 days & ND & ND & ND & SA & $0.16 \pm 0.03$ & ND \\
\hline 73 days & ND & SA & ND & ND & ND & ND \\
\hline 76 days & ND & ND & $\mathrm{ND}$ & $\mathrm{ND}$ & ND & ND \\
\hline 85 days & $\mathrm{ND}$ & ND & ND & ND & SA & ND \\
\hline
\end{tabular}

${ }^{a}$ Sample without herbicide (SH); ${ }^{b}$ blank sample (BR); ${ }^{c}$ concentration below the quantification limit of the technique (ND); ${ }^{d}$ no sample-volume extracted was not enough for the analysis (SA).

and AM2, as a function of time. In both soils, 2,4-D was detected in the deeper layer ( $75 \mathrm{~cm}$ depth) 24 hours after its application on the soil surface. The highest 2,4-D concentration values were detected in the first three days after its application. After one week, practically no 2,4-D was detected in the extracted soil solutions for both soils, according to the measured concentrations and their standard deviations. Figure 5 presents square wave voltammograms of the 2,4-D herbicide measured in the AM1 (Figure 5(a)) and AM2 (Figure 5(b)) extracted soil solutions at $25 \mathrm{~cm}$ depth.
The inserted graphics show the concentration decay as a function of time.

2,4-D concentrations measured in both soils were very similar in terms of spatial dissipation. There were no significant differences in the herbicide spatial distribution for the sandy and clayey soils as measured in the extracted soil solutions. This was probably caused by the anionic behavior of the 2,4-D, exhibiting low sorption on clay minerals (negatively charged) and a negative correlation with $\mathrm{pH}$ and to some extent a positive correlation with OM. These results (Table 3 ) 
TABLE 4: Concentration of 2,4-D in the soil solutions extracted from the soil samples collected with an auger after 100 days of the herbicide application.

\begin{tabular}{lcc}
\hline & Depth & $C_{2,4-\mathrm{D}}\left(\mathrm{mg} \mathrm{Kg}^{-1}\right)$ \\
\hline \multirow{3}{*}{ AM1 } & $0-25 \mathrm{~cm}$ & $\mathrm{ND}^{\mathrm{a}}$ \\
& $25-50 \mathrm{~cm}$ & $0.76 \pm 0.04$ \\
& $50-75 \mathrm{~cm}$ & $0.91 \pm 0.04$ \\
\multirow{2}{*}{ AM2 } & $0-25 \mathrm{~cm}$ & $0.58 \pm 0.03$ \\
& $25-50 \mathrm{~cm}$ & $\mathrm{ND}^{\mathrm{a}}$ \\
& $50-75 \mathrm{~cm}$ & $\mathrm{ND}^{\mathrm{a}}$ \\
\hline
\end{tabular}

${ }^{\mathrm{a}}$ Concentration below the quantification limit of the technique (ND).

show a very low persistence of 2,4-D in the studied soils (around 7-14 days), which is in accordance with the reported half-life for field dissipation of about 10 days reported for the 2,4-D in soils [37].

Herbicides derived from weak acids such as the 2,4-D (pKa 2.8) lose protons and are predominantly in the anionic form in soils ( $\mathrm{pH} 5$ to 8 ) and since soil $\mathrm{pH}$ is higher than the herbicide $\mathrm{pKa}$, the ionized species are predominant. However, a reduction in herbicide sorption due to the negative nature of soil net charge is expected [38, 39]. For this reason, 2,4-D sorption in soils is generally lower than that of cationic or basic herbicides and, therefore, such herbicide is more susceptible to photodegradation and microbiological degradation [40].

After 100 days from the beginning of the experiment, soil samples were collected for residual analysis of 2,4-D in the soils profile. During this period of time the total precipitation was $23.6 \mathrm{~mm}$ and the average temperature and relative humidity were $24.5^{\circ} \mathrm{C}$ and $80 \%$, respectively.

The concentrations of 2,4-D determined at depths 0$25 \mathrm{~cm}, 25-50 \mathrm{~cm}$, and $50-75 \mathrm{~cm}$ are shown in Table 4 . A significant difference in the herbicide concentration along the profile and between the two soils can be verified. The average concentrations obtained in the soil profile $(0$ to $75 \mathrm{~cm}$ of depth) were $0.69 \mathrm{mg} \mathrm{L}^{-1}$ and $0.38 \mathrm{mg} \mathrm{L}^{-1}$ for soils AM1 (sandy) and AM2 (clayey), respectively. These results indicate a higher accumulation of 2,4-D in the sandy soil 100 days after the application on the soil surfaces. This behavior can be attributed to the higher amount of organic matter content in the clayey soil (AM2) compared to the sandy soil (AM1), which provides a favorable environment for herbicide microbiological degradation. Differences in concentration along the soil profile between soils can be explained by higher macroporosity and hydraulic conductivity of the sandy soil (AM1) when compared to the clayey soil AM2.

\section{Conclusions}

The developed electroanalytical procedure using the GPU electrode allowed the direct determination of the herbicide 2,4-D in soil solutions without previous extraction or pretreatment. The obtained limit of detection was adequate in order to study the percolation and sorption behavior of
2,4-D in soils under field conditions. The effect of matrices or soil solution interferences on the electroanalytical responses of the two soils was minimal, as verified in the analytical curves, providing consistent measurements in both porous cup extracted soil solution and solutions extracted from soil samples collected with an auger. The GPU electrode has proved to be an alternative for the direct electroanalytical determination of 2,4-D in soil samples to the conventionally used mercury electrode.

\section{Conflict of Interests}

The authors declare that there is no conflict of interests regarding the publication of this paper.

\section{Acknowledgments}

The authors gratefully acknowledge support from the Brazilian Agricultural Research Corporation (EMBRAPA) under Grant no. 01.05.1.001.02.02 and the Brazilian National Council for the Scientific and Technological Development (CNPq) under Grant no. 301057/2009-5. Special thanks are due to Rene de Oste for his technical support in the field experiments.

\section{References}

[1] "The WHO recommended classification of pesticides by hazard," 2013, http://www.who.int/ipcs/publications/pesticides hazard_rev_3.pdf.

[2] N. Maleki, A. Safavi, and H. R. Shahbaazi, "Electrochemical determination of 2,4-D at a mercury electrode," Analytica Chimica Acta, vol. 530, no. 1, pp. 69-74, 2005.

[3] J. Gaultier, A. Farenhorst, J. Cathcart, and T. Goddard, "Degradation of [carboxyl- ${ }^{14} \mathrm{C}$ ] 2,4-D and [ring-U- ${ }^{14} \mathrm{C}$ ] 2,4-D in 114 agricultural soils as affected by soil organic carbon content," Soil Biology and Biochemistry, vol. 40, no. 1, pp. 217-227, 2008.

[4] Database of Brazilian Environmental Ministry, National Environmental Concil, 2013, http://www.mma.gov.br/port/conama /res/res05/res35705.pdf.

[5] W.-H. Ding, C.-H. Liu, and S.-P. Yeh, "Analysis of chlorophenoxy acid herbicides in water by large-volume on-line derivatization and gas chromatography-mass spectrometry," Journal of Chromatography A, vol. 896, no. 1-2, pp. 111-116, 2000.

[6] E. A. Hogendoorn, R. Huls, E. Dijkman, and R. Hoogerbrugge, "Microwave assisted solvent extraction and coupled-column reversed-phase liquid chromatography with UV detection: use of an analytical restricted-access-medium column for the efficient multi-residue analysis of acidic pesticides in soils," Journal of Chromatography A, vol. 938, no. 1-2, pp. 23-33, 2001.

[7] N. Rosales-Conrado, M. E. León-González, L. V. Pérez-Arribas, and L. M. Polo-Díez, "Determination of chlorophenoxy acid herbicides and their esters in soil by capillary high performance liquid chromatography with ultraviolet detection, using large volume injection and temperature gradient," Analytica Chimica Acta, vol. 470, no. 2, pp. 147-154, 2002. 
[8] O. P. de Amarante Jr., N. M. Brito, T. C. R. Dos Santos, G. S. Nunes, and M. L. Ribeiro, "Determination of 2,4dichlorophenoxyacetic acid and its major transformation product in soil samples by liquid chromatographic analysis," Talanta, vol. 60, no. 1, pp. 115-121, 2003.

[9] A. B. Vega, A. G. Frenich, and J. L. M. Vidal, "Monitoring of pesticides in agricultural water and soil samples from Andalusia by liquid chromatography coupled to mass spectrometry," Analytica Chimica Acta, vol. 538, no. 1-2, pp. 117-127, 2005.

[10] B. B. Dzantiev, A. V. Zherdev, M. F. Yulaev, R. A. Sitdikov, N. M. Dmitrieva, and I. Y. Moreva, "Electrochemical immunosensors for determination of the pesticides 2,4-dichlorophenoxyacetic and 2,4,5-trichlorophenoxyacetic acids," Biosensors and Bioelectronics, vol. 11, no. 1-2, pp. 179-185, 1996.

[11] E. P. Medyantseva, M. G. Vertlib, M. P. Kutyreva, E. I. Khaldeeva, G. K. Budnikov, and S. A. Eremin, "The specific immunochemical detection of 2,4-dichlorophenoxyacetic acid and 2,4,5-trichlorophenoxyacetic acid pesticides by amperometric cholinesterase biosensors," Analytica Chimica Acta, vol. 347, no. 1-2, pp. 71-78, 1997.

[12] M. Dequaire, C. Degrand, and B. Limoges, "An immunomagnetic electrochemical sensor based on a perfluorosulfonatecoated screen-printed electrode for the determination of 2,4dichlorophenoxyacetic acid," Analytical Chemistry, vol. 71, no. 13, pp. 2571-2577, 1999.

[13] J. C. Chuang, J. M. van Emon, J. Durnford, and K. Thomas, "Development and evaluation of an enzyme-linked immunosorbent assay (ELISA) method for the measurement of 2,4-dichlorophenoxyacetic acid in human urine," Talanta, vol. 67, no. 3, pp. 658-666, 2005.

[14] O. P. de Amarante Jr., T. C. R. dos Santos, G. S. Nunes, and M. L. Ribeiro, "Concise revision of methods for determination of the herbicide dichlorophenoxyacetic acid (2,4-D)," Quimica Nova, vol. 26, no. 2, pp. 223-229, 2003.

[15] R. Inam, E. Z. Gülerman, and T. Sarigül, "Determination of triflumizole by differential pulse polarography in formulation, soil and natural water samples," Analytica Chimica Acta, vol. 579, no. 1, pp. 117-123, 2006.

[16] H. Mercan and R. Inam, "Determination of the fungicide anilazine in soil and river water by differential pulse polarography," Clean-Soil, Air, Water, vol. 36, no. 10-11, pp. 913-919, 2008.

[17] T. Thriveni, J. R. Kumar, J. Y. Lee, and N. Y. Sreedhar, "Study of the voltammetric behaviour of the ethalfluralin and methalpropalin and its determination in environmental matrices at hanging mercury drop electrode," Environmental Monitoring and Assessment, vol. 151, no. 1-4, pp. 9-18, 2009.

[18] C. G. Bauer, A. V. Eremenko, E. Foster-Ehrentreich et al., "Zeptomole-detecting biosensor for alkaline phosphatase in an electrochemical immunoassay for 2,4-dichlorophenoxyacetic acid," International Journal of Computer Vision, vol. 18, no. 3, pp. 2453-2458, 1996.

[19] T. Kaláb and P. Skládal, "Disposable multichannel immunosensors for 2,4-dichlorophenoxyacetic acid using acetylcholinesterase as an enzyme label," Electroanalysis, vol. 9, no. 4, pp. 293-297, 1997.

[20] F. Mazzei, F. Botrè, S. Montilla, R. Pilloton, E. Podestà, and C. Botrè, "Alkaline phosphatase inhibition based electrochemical sensors for the detection of pesticides," Journal of Electroanalytical Chemistry, vol. 574, no. 1, pp. 95-100, 2004.
[21] F. R. Simões, L. H. C. Mattoso, and C. M. P. Vaz, "Modified carbon paste-polyaniline electrodes for the electrochemical determination of the herbicide 2,4-D," Sensor Letters, vol. 2, no. 3-4, pp. 221-225, 2004.

[22] S. Chaiyasith, T. Tangkuaram, and P. Chaiyasith, "Electrocatalytical of chlorophenoxycarboxylic acids at a protoporphyrin IX cobalt(III) chloride modified glassy carbon electrode," Journal of Electroanalytical Chemistry, vol. 581, no. 1, pp. 104-110, 2005.

[23] Z. Wang, J. Kang, X. Liu, and Y. Ma, "Voltammetric response of 2,4-D-molecularly imprinted film modified glassy carbon electrodes," Indian Journal of Chemistry A, vol. 45, no. 8, pp. 1848-1851, 2006.

[24] F. R. Simões, L. H. Capparelli Mattoso, and C. M. P. Vaz, "Conducting polymers as sensor materials for the electrochemical detection of pesticides," Sensor Letters, vol. 4, no. 3, pp. 319-324, 2006.

[25] T. Navratil and J. Barek, "Analytical applications of composite solid electrodes," Critical Reviews in Analytical Chemistry, vol. 39, no. 3, pp. 131-147, 2009.

[26] R. K. Mendes, S. Claro-Neto, and E. T. G. Cavalheiro, "Evaluation of a new rigid carbon-castor oil polyurethane composite as an electrode material," Talanta, vol. 57, no. 5, pp. 909-917, 2002.

[27] R. A. de Toledo, M. C. Santos, E. T. G. Cavalheiro, and L. H. Mazo, "Determination of dopamine in synthetic cerebrospinal fluid by SWV with a graphite-polyurethane composite electrode," Analytical and Bioanalytical Chemistry, vol. 381, no. 6, pp. 1161-1166, 2005.

[28] R. A. de Toledo, M. C. Santos, K. M. Honório, A. B. F. da Silva, E. T. G. Cavalheiro, and L. H. Mazo, "Use of graphite polyurethane composite electrode for imipramine oxidation-mechanism proposal and electroanalytical determination," Analytical Letters, vol. 39, no. 3, pp. 507-520, 2006.

[29] P. Cervini, L. A. Ramos, and E. T. G. Cavalheiro, "Determination of atenolol at a graphite-polyurethane composite electrode," Talanta, vol. 72, no. 1, pp. 206-209, 2007.

[30] A. R. Malagutti, V. G. Zuin, E. T. G. Cavalheiro, and L. H. Mazo, "Determination of rutin in green tea infusions using squarewave voltammetry with a rigid carbon-polyurethane composite electrode," Electroanalysis, vol. 18, no. 10, pp. 1028-1034, 2006.

[31] R. A. de Toledo and C. M. P. Vaz, "Use of a graphitepolyurethane composite electrode for electroanalytical determination of indole-3-acetic acid in soil samples," Microchemical Journal, vol. 86, no. 2, pp. 161-165, 2007.

[32] J. C. Miller and J. N. Miller, Statistics for Analytical Chemistry, Ellis Horwood PTR Prentice-Hall, New York, NY, USA, 1993.

[33] A. Arranz, I. Dolara, S. F. de Betoño, J. M. Moreda, A. Cid, and J. F. Arranz, "Electroanalytical study and square wave voltammetric techniques for the determination of $\beta$-blocker timolol at the mercury electrode," Analytica Chimica Acta, vol. 389, no. 1-3, pp. 225-232, 1999.

[34] D. K. Gosser Jr., Cyclic Voltammetry Simulation and Analysis of Reaction Mechanisms, VCH Publishers, New York, NY, USA, 1994.

[35] A. G. S. Prado, H. T. Barcelos, A. O. Moura, A. R. Nunes, and E. S. Gil, "Dichlorophenoxyacetic acid anchored on silica-gel modified carbon paste for the determination of pesticide 2,4D," International Journal of Electrochemical Science, vol. 7, pp. 8929-8939, 2012. 
[36] C. Xie, S. Gao, Q. Guo, and K. Xu, "Electrochemical sensor for 2,4-dichlorophenoxy acetic acid using molecularly imprinted polypyrrole membrane as recognition element," Microchimica Acta, vol. 169, no. 1, pp. 145-152, 2010.

[37] R. D. Wauchope, T. M. Buttler, A. G. Hornsby, P. W. M. Augustijn-Beckers, and J. P. Burt, "The SCS/ARS/CES pesticide properties database for environmental decision-making," Reviews of Environmental Contamination and Toxicology, vol. 123, pp. 1-155, 1992.

[38] S. B. Weed and J. B. Weber, Pesticides in Soil and Water, edited by W. D. Guenzi, Soil Science Society of America, Madison, Wis, USA, 1986.

[39] R. S. Oliveira Jr., W. C. Koskinen, and F. A. Ferreira, "Sorption and leaching potential of herbicides on Brazilian soils," Weed Research, vol. 41, no. 2, pp. 97-110, 2001.

[40] W. G. Johnson, T. L. Lavy, and E. E. Gbur, "Sorption, mobility and degradation of triclopyr and 2,4-D on four soils," Weed Science, vol. 43, no. 4, pp. 678-684, 1995. 

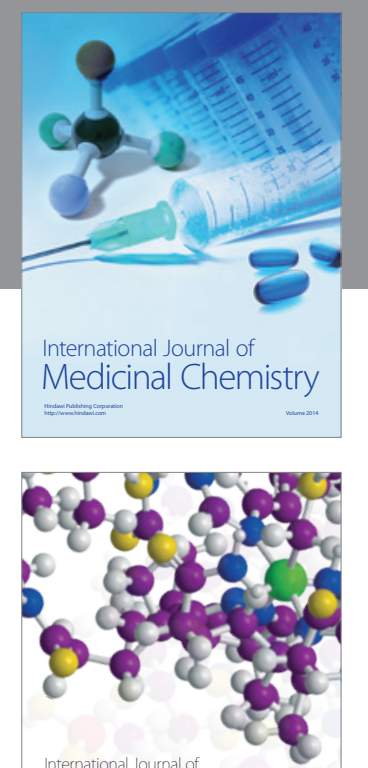

\section{Carbohydrate} Chemistry

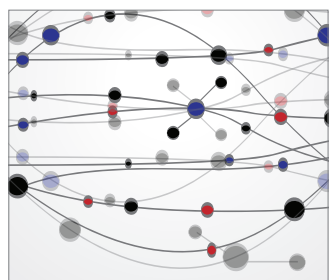

The Scientific World Journal
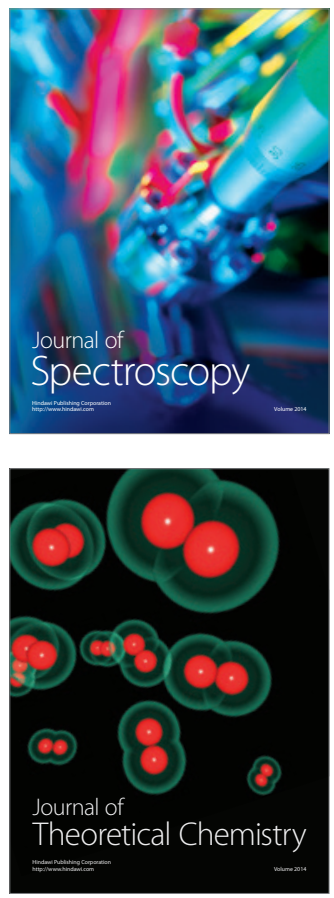
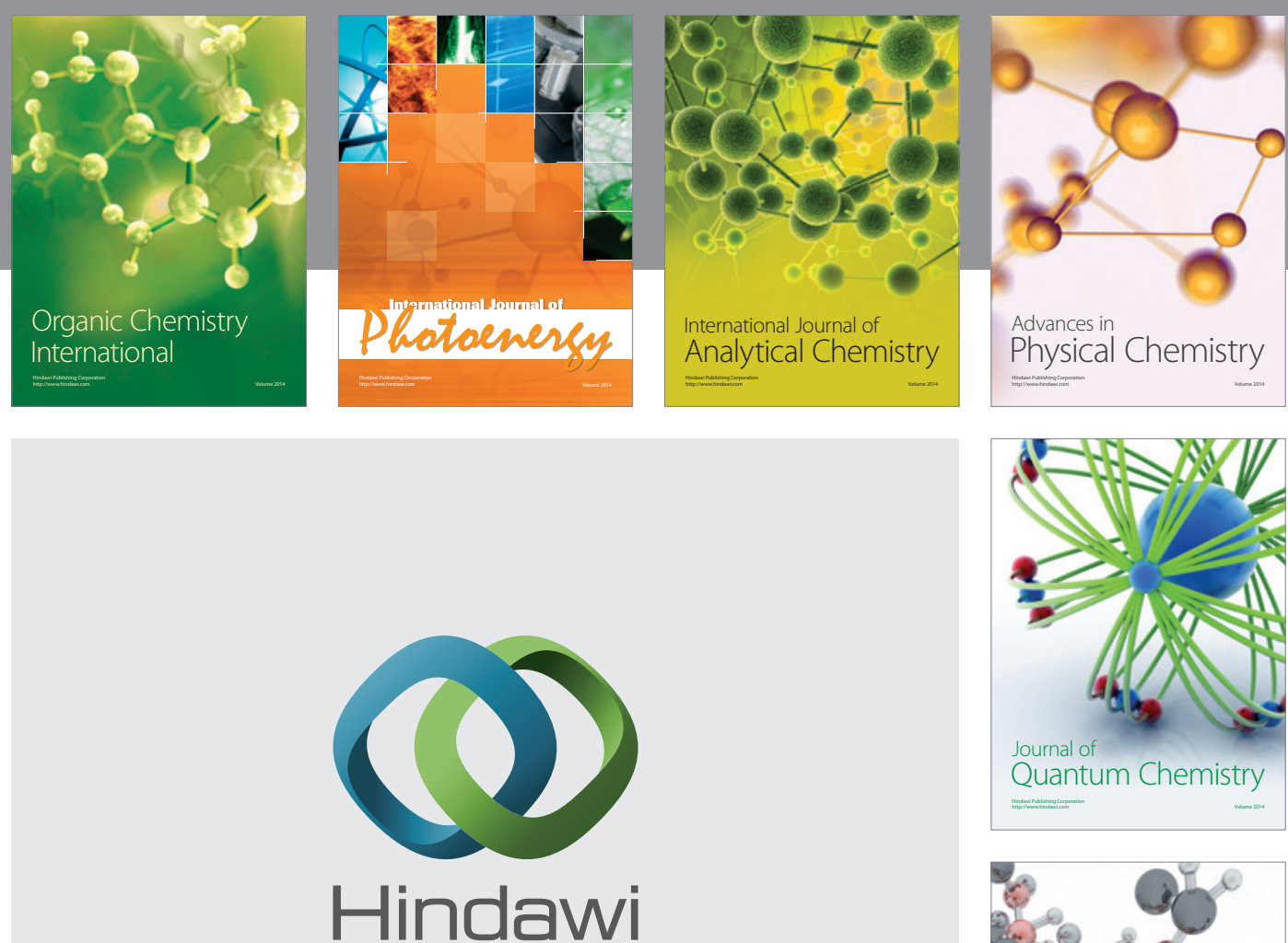

Submit your manuscripts at

http://www.hindawi.com

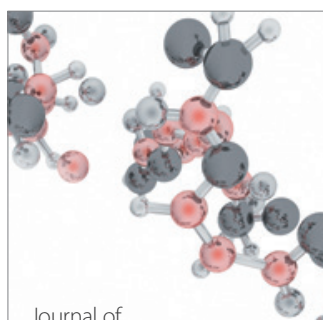

Analytical Methods

in Chemistry

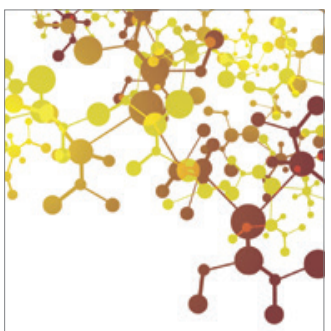

Journal of

Applied Chemistry

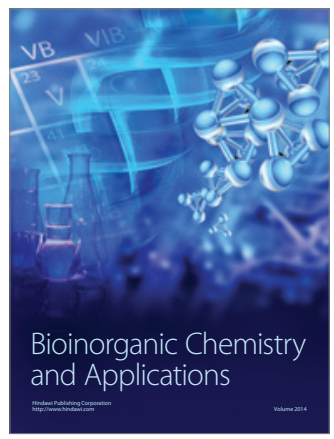

Inorganic Chemistry
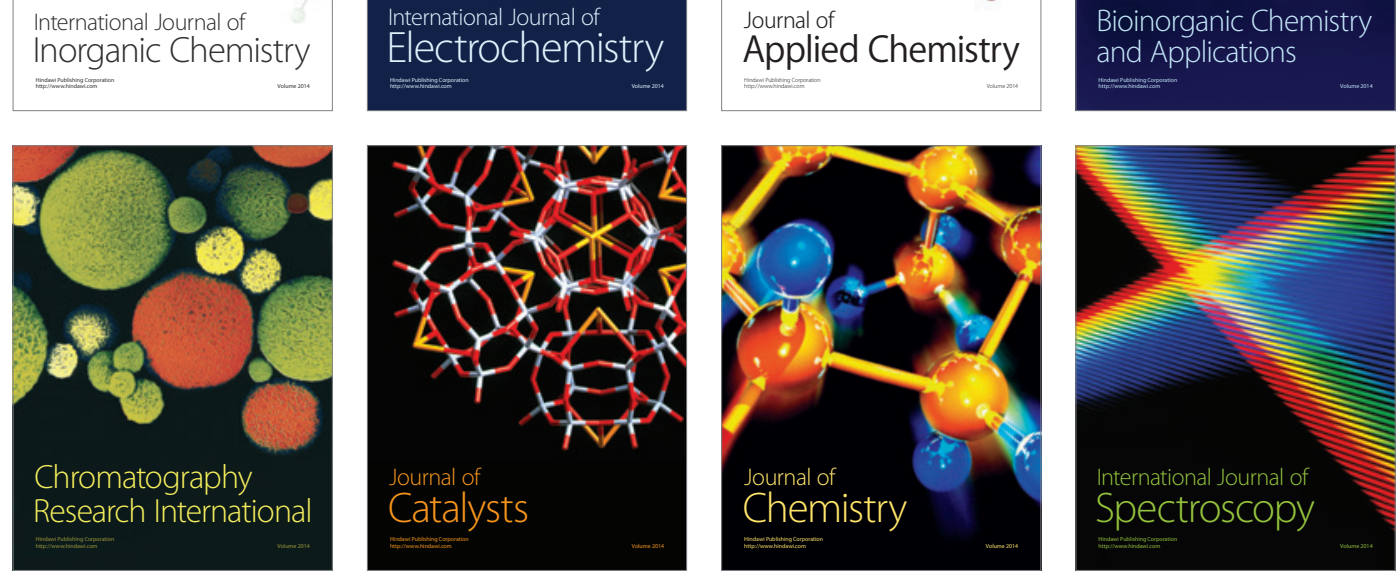